\title{
Acoustic niche partitioning in an anuran community from the municipality of Floriano, Piauí, Brazil
}

\author{
M. S. C. S. Lima a , J. Pederassi ${ }^{b, c *}$, R. B. Pineschic and D. B. S. Barbosa ${ }^{a}$ \\ aUniversidade Federal do Piauí - UFPI, Campus Amilcar Ferreira Sobral, BR 343, Km 3,5, CEP 64800-000, Floriano, PI, Brasil \\ ${ }^{\text {b}}$ Departamento de Vertebrados, Museu Nacional - MN, Universidade Federal do Rio de Janeiro - UFRJ, \\ Quinta da Boa Vista, São Cristóvão, CEP 20940-040, Rio de Janeiro, RJ, Brasil \\ 'Ong Bioma, Rua Queluz, 125, São Cristóvão, CEP 27264-820, Volta Redonda, RJ, Brasil \\ *e-mail: jonaspederassi@yahoo.com.br
}

Received: May 23, 2017 - Accepted: February 21, 2018 - Distributed: November 30, 2019

(With 14 figures)

\begin{abstract}
Vocalizations are an important trait for the identification of cryptic and/or closely related amphibian species. Different vocalizations also contribute to partitioning of the acoustic space by sympatric species. This study aimed to describe the advertisement calls of anurans in a pond of the municipality of Floriano, State of Piauí, Brazil, and infer the acoustic niche partitioning of amphibians. Euclidean distance was used in a cluster analysis approach to infer the acoustic similarities among species. Thirteen species were analysed: Boana raniceps, Dendropsophus nanus, D. rubicundulus, D. minutus, Leptodactylus fuscus, L. troglodytes, L. vastus, Pithecopus nordestinus, Physalaemus cuvieri, P. nattereri, Pleurodema diplolister, Proceratophrys cristiceps and Scinax ruber. From these, six showed more than $90 \%$ of acoustic overlap: P. nattereri, P. cuvieri, L. fuscus and L. vastus (Leptodactylidae); and, D. nanus and D. rubicundulus (Hylidae). Despite the acoustic similarities among these six species, the acoustic interference was reduced due to the small number of sympatric species and to distinct features on carrier frequency such as dominant frequency and the degree of modulation in the frequency. Environmental factors limit the periods and sites of reproduction respectively, which may maintain the low anuran diversity and consequently reduce acoustic overlap.
\end{abstract}

Keywords: advertisement calls, bioacoustics, Hylidae, Leptodactylidae, Odontophrynidae.

\section{Partição de nicho acústico em uma comunidade de anuros do município de Floriano, Piauí, Brasil}

\section{Resumo}

A vocalização é um componente importante na identificação de espécies crípticas e/ou proximamente relacionadas de anfíbios anuros. Diferenças na bioacústica também contribuem para o particionamento do espaço acústico entre espécies simpátricas. Este estudo descreve o canto de anúncio de anuros em uma lagoa temporária do município de Floriano, Estado do Piauí, Brasil, além de buscar inferir o particionamento do nicho acústico entre essas espécies. Para tanto, foi utilizada a distância Euclidiana para compor uma análise de conglomerados e avaliar a similaridade/dissimilaridade da bioacústica da anurofauna. Treze espécies foram amostradas: Boana raniceps, Dendropsophus nanus, D. rubicundulus, D. minutus, Leptodactylus fuscus, L. troglodytes, L. vastus, Pithecopus nordestinus, Physalaemus cuvieri, P. nattereri, Pleurodema diplolister, Proceratophrys cristiceps e Scinax ruber. Destas, seis apresentaram mais de 90\% de sobreposição acústica: P. nattereri, P. cuvieri, L. fuscus e L. vastus (Leptodactylidae); e, D. nanus e D. rubicundulus (Hylidae). Apesar da similaridade acústica entre essas seis espécies, a interferência é reduzida devido ao pequeno número de espécies simpátricas e certas características distintas na frequência do canto, tais como: frequência dominante e sua modulação. Fatores ambientais específicos do semiárido limitam os períodos e sítios reprodutivos, o que mantém baixa diversidade de espécies e consequentemente reduz a sobreposição no nicho acústico.

Palavras-chave: canto de anúncio, bioacústica, Hylidae, Leptodactylidae, Odontophrynidae.

\section{Introduction}

Vocalization is an important component of the reproductive behaviour of most anuran species (Gerhardt, 1994; Gerhardt and Huber, 2002). The advertisement call is the most common type of vocalization, functioning primarily to attract females (Duellman and Trueb, 1994; Gerhardt, 1994). It has evolved to reduce the acoustic interferences 
between sympatric species (Martins and Jim, 2003; 2004, Silva et al., 2008). Due to its relatively invariant features, it can be as useful as a morphological trait in the taxonomy of anuran species (Gerhardt and Huber, 2002).

Taxonomic studies using species vocalization patterns first appeared during the 1920`s (Ryan, 2001). Since then, vocalization has been considered an important tool in the characterization of anurans, complementing the identification of morphologically similar or cryptic species (Heyer and Reid, 2003; Bastos et al., 2011). Besides the taxonomic importance of the bioacoustics, this tool can be used to improve our knowledge about the partitioning of space by anurans (Sinsch et al., 2012), especially in megadiverse environments such as the neotropics. Krause (1987) understood that the study of animal vocalization was linked not to the interspecific call or to biocenosis, but to the place where vocalization occurs, establishing a unique and exclusive bioacoustic spectrum of the place where the community partitions the acoustic niche. Modern biogeography studies this natural acoustic phenomenon through the ecology of sound space investigating the density, occurrence and behavioral activities of populations and communities (Lomolino et al., 2015).

Several studies have investigated the bioacoustics of anurans in Brazil. However, most are limited to the Atlantic Forest, especially in southeast Brazil (e.g. Heyer et al., 1990; Bastos and Haddad, 1999; Wogel et al., 2002; Pombal-Jr, 2010). Therefore, there is a lack of knowledge on anuran bioacoustics in the central regions of Brazil, with only incipient information available for other biomes, such as the Cerrado (Bastos et al., 2011). Furthermore, bioacoustic descriptions, even regarding well known species, are important for comparative purposes when performed in different regions (Heyer and Reid, 2003).

The present study sought to: (1) improve the knowledge about the diversity of anurans in the municipality of Floriano, State of Piauí, Brazil, using bioacoustics features; (2) provide a detailed description of the advertisement calls of species from this region, and; (3) infer acoustic niche overlap between these species, through the analysis of advertisement calls.

\section{Material and Methods}

\subsection{Study site}

The study site is a single broad flooded area located in the coordinates $43^{\circ} 00^{\prime} 43^{\prime \prime} \mathrm{W} ; 6^{\circ} 46^{\prime} 24^{\prime}$ ' S, $113 \mathrm{~m}$ a.s.1.. It is inserted in the domain of the Cerrado biome in a micro-region of southern Piauí known as Chapada and Chapadões do Meio Norte, border of the Parnaíba river. The climate is tropical and semiarid with average annual temperature of $27^{\circ} \mathrm{C}$, and rainfall of $1060 \mathrm{~mm}$ (PMF, 2015).

The study area lies within a peri-urban zone dominated by deciduous xerophilous arborescent vegetation. The focal vegetation fragment covers an area of $8,236 \mathrm{~m}^{2}$, being limited in the west by the BR 343 Road, in the east by the Amilcar Ferreira Sobral University Campus, in the south by an unpaved road and in the north by a private rural property composed of pasture land that encompasses a $400 \mathrm{~m}^{2}$ seasonal floodplain of $60 \mathrm{~cm}$ depth.

Data on relative humidity $(\mathrm{RH} \%)$, temperature $\left({ }^{\circ} \mathrm{C}\right)$ and rainfall $(\mathrm{mm})$ were provided by the Floriano Meteorological Station, located $5 \mathrm{~km}$ from the study site (INMET, 2015). During the sampling period the relative humidity averaged ( \pm standard deviation) was $73 \pm 0.09 \%$ (50 to $94 \%$ ) and temperature $26.96 \pm 1.89{ }^{\circ} \mathrm{C}\left(21.40\right.$ to $\left.31.30{ }^{\circ} \mathrm{C}\right)$, while rainfall averaged $7.36 \pm 10.30$ ( 0 to 57.1$) \mathrm{mm} /$ day.

\subsection{Data gathering and analyses}

The field study was carried out from November 2011 to March 2012, with three days of sample in each month, from $18 \mathrm{~h} 00 \mathrm{~min}$ to $23 \mathrm{~h} 00 \mathrm{~min}$ approximately, totalizing 15 days ( 75 hours) of field sample.

The species vocalizations were recorded with a digital recorder (Roland Edirol R1 Wave 24 bits) attached to a microphone (Yoga HT81 Super uni-directional electric condenser) to record the vocalizations. The microphone was positioned approximately $70 \mathrm{~cm}$ from the species during the vocalization. The bioacoustic analyses and its relative figures were performed using Raven Pro 1.4 (Cornell Lab, 2011) software with sampling rate of $44.1 \mathrm{KHz}$ and 16 bits of resolution, with FFT size of 512 points and Window type in Hanning for better spectrogram resolution.

The determination of the advertisement call of the species analysed in the present study follows: Toledo et al. (2014) to Dendropsophus minutus - in this species we recorded only the call type A, according Toledo et al. (2014); Martins and Jim (2003) to Dendropsophus nanus; Cardoso and Vielliard (1985) to Dendropsophus rubicundulus; Guimarães and Bastos (2003) to Boana raniceps; Vilaça et al. (2011) to Pithecopus nordestinus; Bernal et al. (2004) to Scinax ruber; Heyer and Reid (2003) to Leptodactylus fuscus; Nunes and Juncá (2006) to Leptodactylus troglodytes and Proceratophrys cristiceps; Jansen and Schulze (2012) to Leptodactylus vastus; Gambale and Bastos (2014) to Physalaemus cuvieri; Bastos et al. (2003) to Physalaemus nattereri; Hödl (1992) to Pleurodema diplolister.

The collected specimens and its respective vocalizations were housed in the Coleção de História Natural da Universidade Federal do Piauí (CHNUFPI), campus Amilcar Ferreira Sobral, municipality of Floriano, Piauí, Brazil.

During the analyses the following acoustic variables were assessed: call duration (in second $=\mathrm{s}$ ), interval between consecutive calls (s), number of notes (notes/call), duration of notes (s), number of pulses per note, duration of pulses (s), dominant frequency $(\mathrm{Hz})$, modulation of dominant frequency $(\mathrm{Hz})$ and repetition rate (notes/s) (Kok and Kalamandeen, 2008; Köhler et al., 2017). The results were expressed in the format average \pm standard deviation $(\mathrm{x} \pm \mathrm{SD})$. To assess the homogeneity of pulse duration, within species, for calls structured in pulses, we used an ANOVA, with significance level of $p<0.05$. The similarity in the use of acoustic parameters by the species was assessed by cluster analysis using the simple aggregation method and Euclidian distance (Legendre and Legendre, 1998). To infer what bioacoustics parameters, among the evaluated 
ones, were the main responsible for the differentiation of the advertisement calls was used the PCA (Principal Component Analysis).

\section{Results}

We recorded advertisement calls of 32 individuals distributed in 13 anurans species (see Figures 1 to 13) from three different families: Physalaemus cuvieri Fitzinger, 1826; Physalaemus nattereri (Steindachner, 1863); Pleurodema diplolister (Peters, 1870); Leptodactylus fuscus (Schneider, 1799); L. troglodytes A. Lutz, 1926, L. vastus A. Lutz, 1930 (Leptodactylidae); Boana raniceps Cope, 1862, Scinax ruber (Laurenti, 1768), Dendropsophus nanus (Boulanger, 1889), D. rubicundulus (Reinhardt \& Lütken, 1862), D. minutus (Ahl, 1933) (Hylidae), Pithecopus nordestinus (Caramaschi, 2006) (Phyllomedusidae); and Proceratophrys cristiceps (Müller, 1884) (Odontophrynidae). Their bioacoustic features are summarized in Table 1.
Among the 13-species found, 10 have pulsed structured calls (see Köhler et al., 2017 for definition of pulsed structures). According to ANOVA only three of these species had non-significant differences between pulses duration: $B$. raniceps, $S$. ruber and $P$. cristiceps showed pulses with similar duration in each note (see Table 2).

Species with modulation in the frequency showed ascending or descending modulation only, except $D$. minutus that showed a tenuous ascending frequency modulation until penultimate pulse, with the last pulse returning to the same frequency of the first one (see Figure 8).

\subsection{Bioacoustic similarities and niche overlap}

Of 13 species analyzed, six showed more than $90 \%$ of acoustic overlapping, being divided in two groups: (i) P. nattereri, P. cuvieri, L. fuscus and L. vastus in the Leptodactylidae family; and (ii) D. nanus and D. rubicundulus in Hylidae family (see Figure 14).

The bioacoustic analysis grouped most of the sampled species accordingly to their current classification in families,

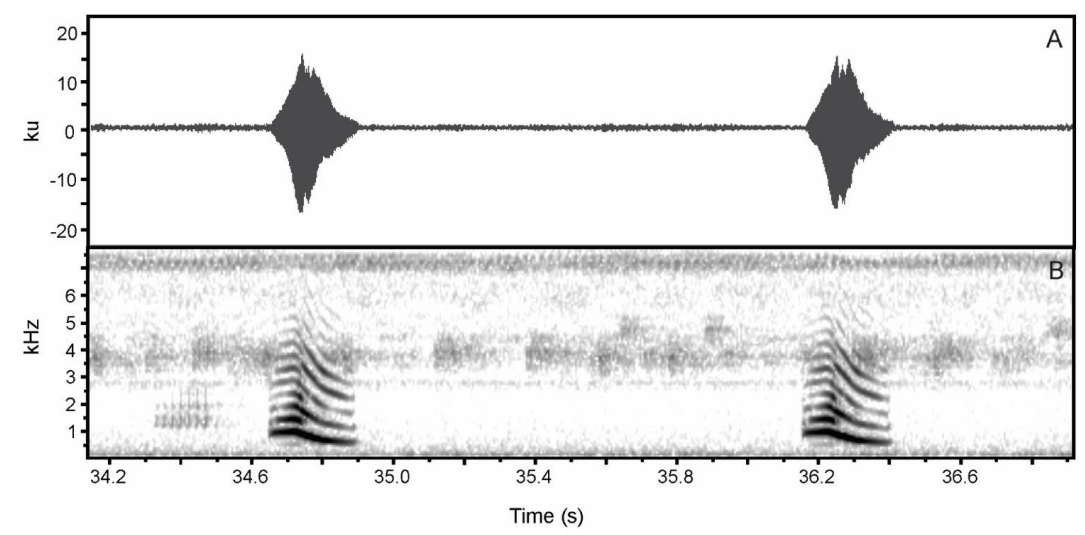

Figure 1. (A) Sound oscillogram displaying the patterns of two advertisement calls of Physalaemus cuvieri. (B) their respective spectrogram.

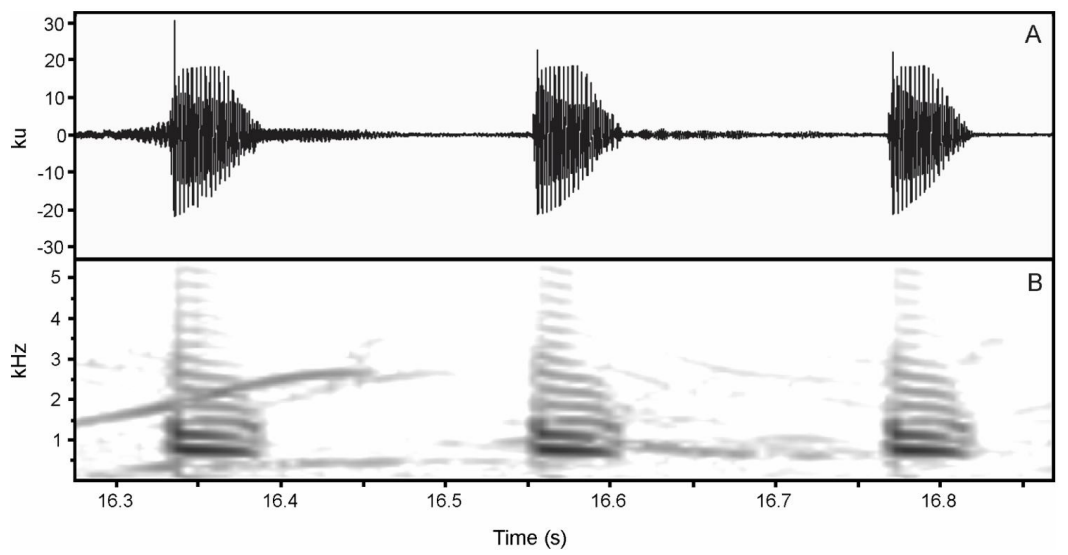

Figure 2. (A) Sound oscillogram displaying the patterns of three advertisement calls of Physalaemus nattereri, and (B) their respective spectrogram. 


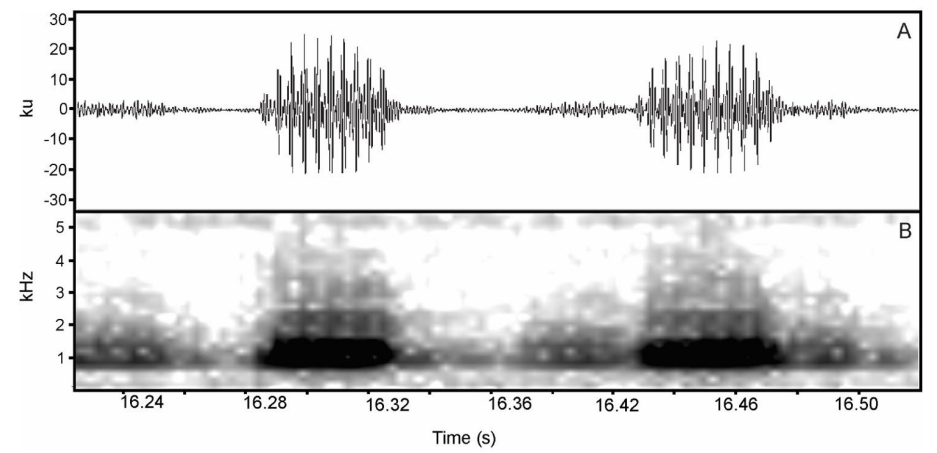

Figure 3. (A) Sound oscillogram displaying two advertisement calls of Pleurodema diplolister. (B) their respective spectrogram.

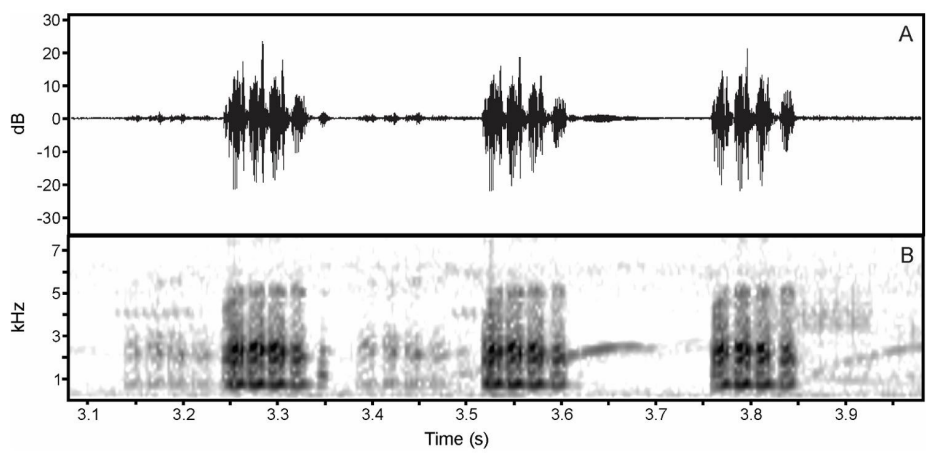

Figure 4. (A) Sound oscillogram of the advertisement call of Boana raniceps showing three notes, and (B) their respective spectrogram.

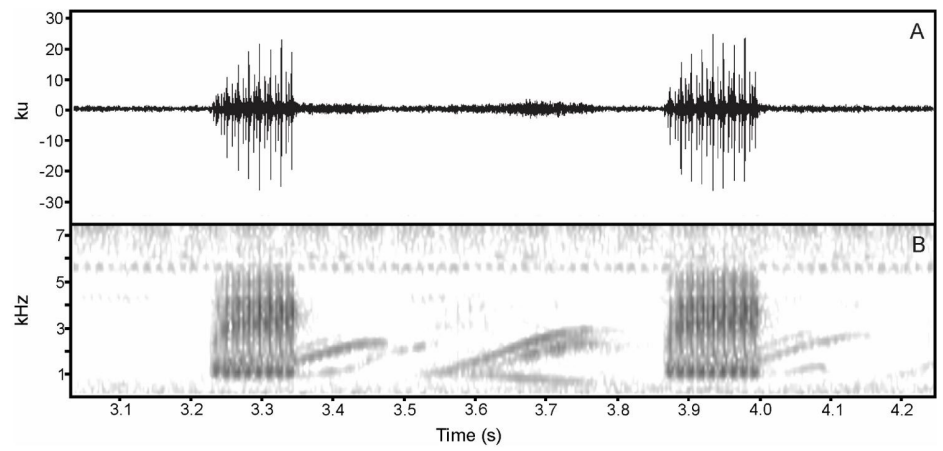

Figure 5. (A) Sound oscillogram of two advertisement calls of Scinax ruber, and (B) their respective spectrogram.

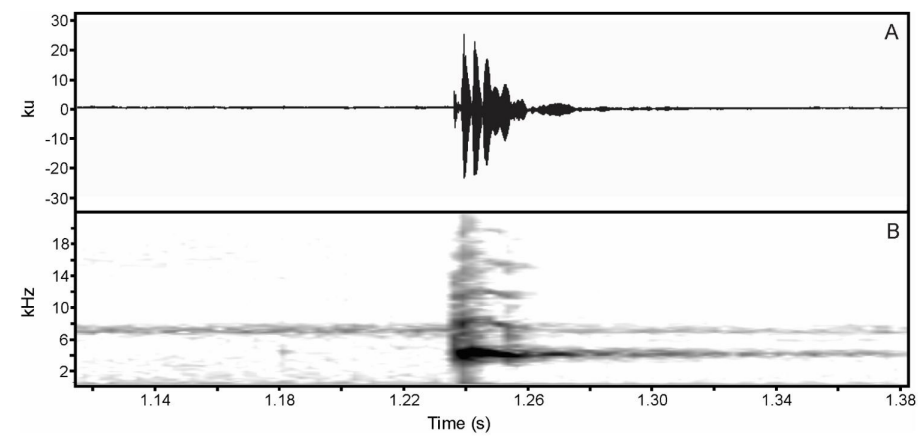

Figure 6. (A) Sound oscillogram of an advertisement call of Dendropsophus nanus, and (B) its respective spectrogram. 


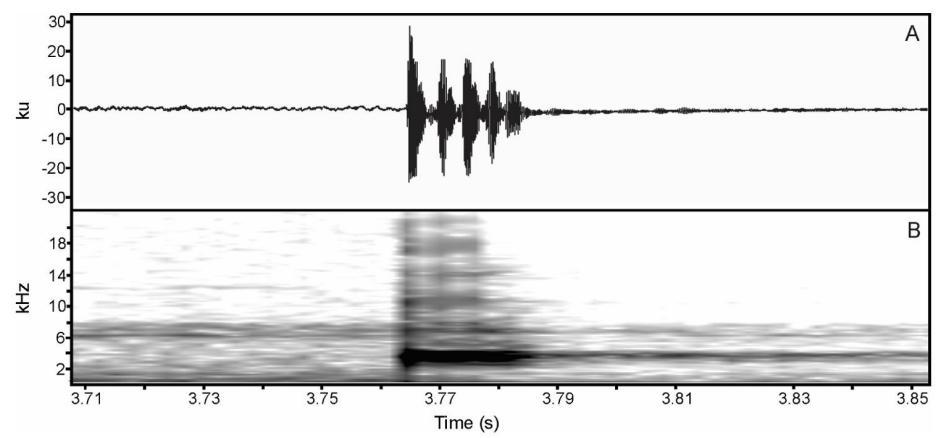

Figure7. (A) Sound oscillogram of an advertisement call of Dendropsophus rubicundulus, and (B) its respective spectrogram.

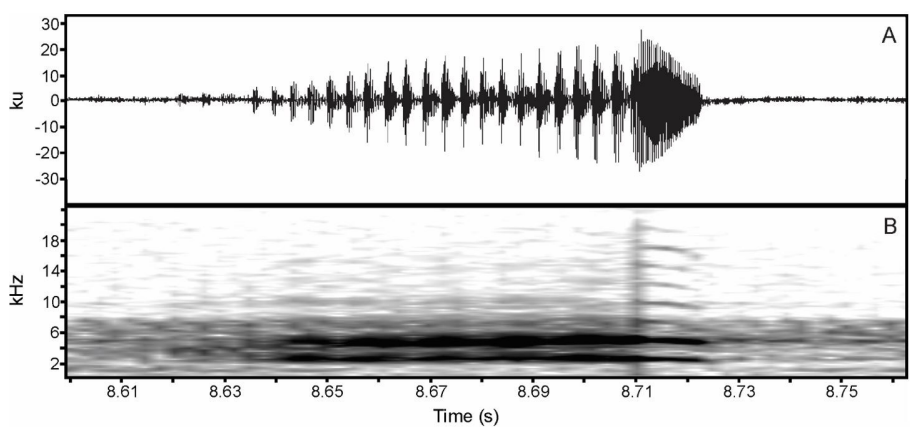

Figure 8. (A) sound oscillogram displaying an advertisement call of Dendropsophus minutus. (B) its respective spectrogram showing the tenuous positive modulation until the last pulse when it starts decay.

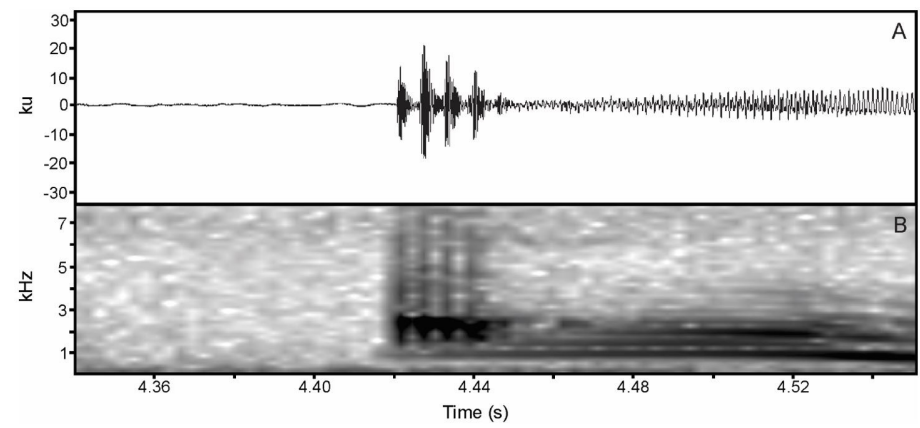

Figure 9. (A) Sound oscillogram of an advertisement call of Pithecopus nordestinus composed of five pulses, and (B) its respective spectrogram.

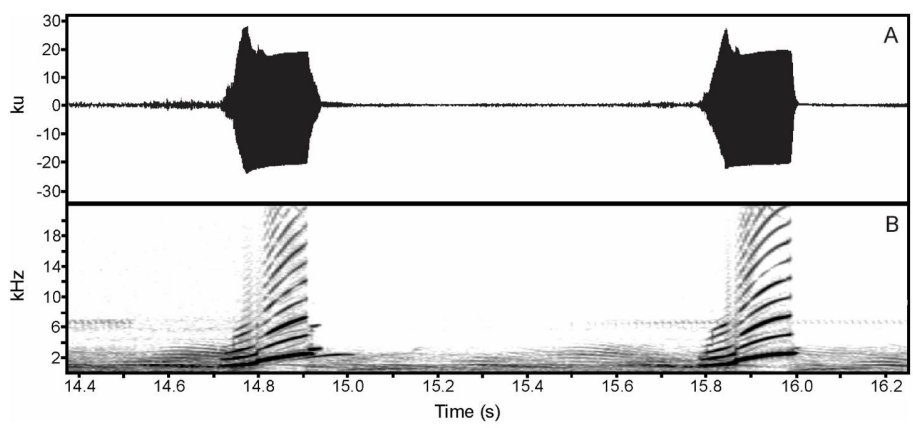

Figure 10. (A) Sound oscillogram of two advertisement calls of Leptodactylus fuscus. (B) their respective spectrogram. 


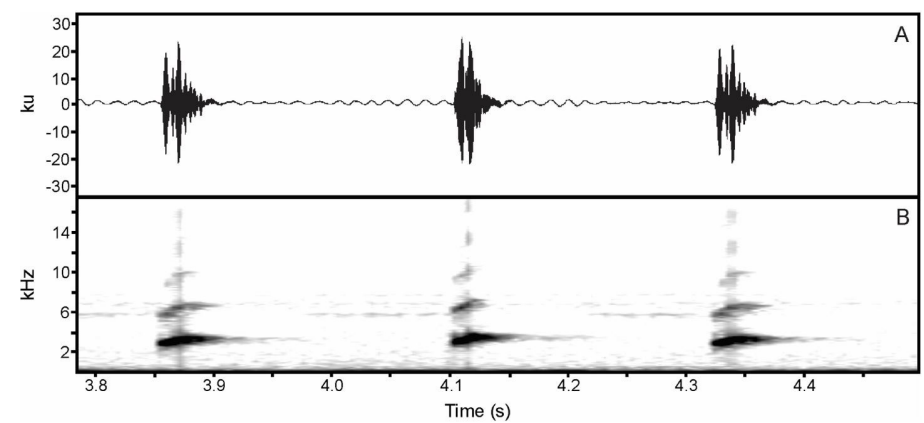

Figure 11. (A) sound oscillogram displaying three advertisement calls of Leptodactylus troglodytes. (B) their respective spectrogram.

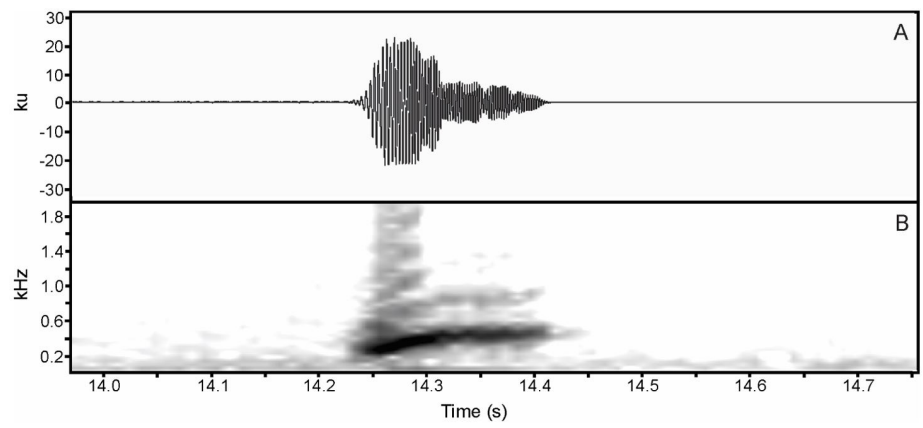

Figure 12. (A) Sound oscillogram of an advertisement call of Leptodactylus vastus. (B) Its respective spectrogram.

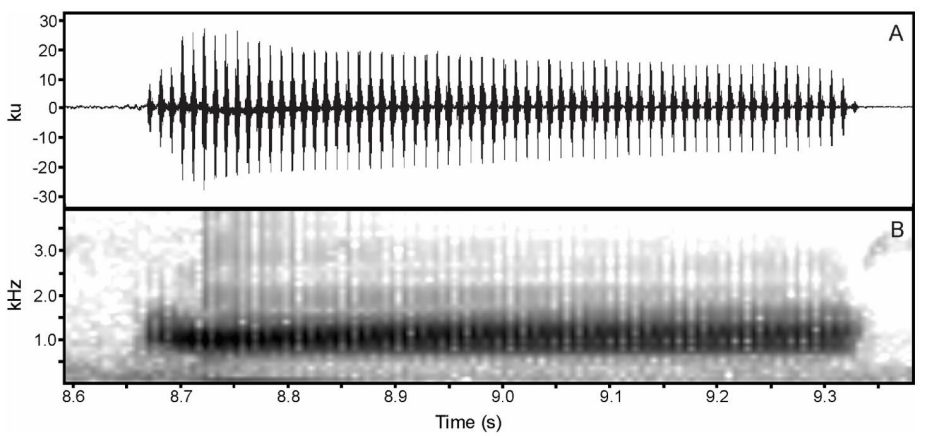

Figure 13. (A) Sound oscillogram of an advertisement call of Proceratophrys cristiceps. (B) its respective spectrogram.

subfamilies and genera (see Figure 14). The cluster analyses separated the families Hylidae and Phyllomedusidae, as well as the genera Dendropsophus, Boana and Scinax. On the other hand, Pleurodema diplolister was not grouped with the other species from the Leptodactylidae family.

According to the PCA, the first component $(\mathrm{CP} 1=$ duration of notes) of the analysis explains $38.9 \%$ of the total variation. The second component (CP2 = dominant frequency) explains $32.1 \%$. The third component $(\mathrm{CP} 3=$ modulation of the dominant frequency) explains $28 \%$ of the variation. The species Dendropsophus minutus, Pleurodema diplolister and Proceratophrys cristiceps are the species with higher acoustic differences, considering the principal components CP1, CP2 and CP3.

\section{Discussion}

Martins et al. (2006), Silva et al. (2008) and Pombal Junior (2010) studied the vocalization of anurocenose in a conventional and punctual way, in our study we sought to understand the interaction between specific vocalizations and their vocal personalities, which were adjusted in the analysis of the vocal conglomerate (Figure 14). Frequency, temporal domain, and spatial domain guarantee acoustic success for each species, even in the face of the local multidimensional spectrum (Pijanowski et al., 2011). However, in studies developed by Schimidt et al. (2015), was not identified which selective pressures establish the sound phenotype, these studies demonstrate that this 


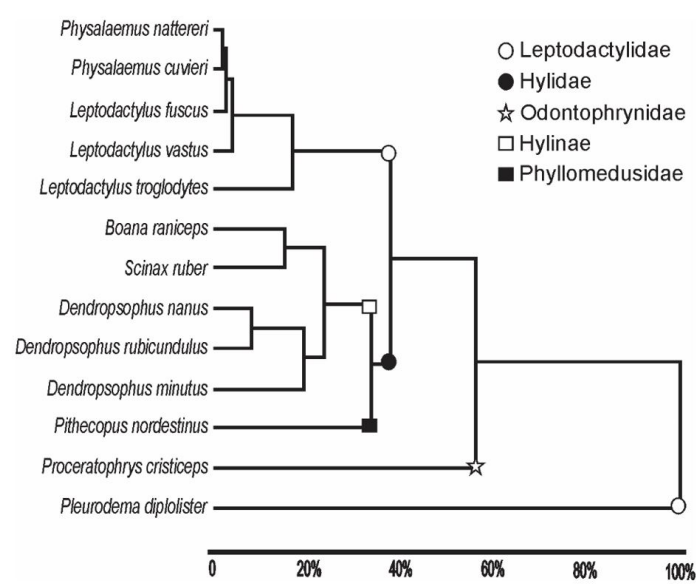

Figure 14. Dendrogram showing the acoustic similarity among the 13 species of amphibians anurans identified in the present study. The percentage describes the levels of dissimilarity according to Euclidian distance and simple linkage.

field of science that seeks to establish the space of sound ecology, requires a bigger sample, because at the moment information is incipient.

The main selective pressure that justifies acoustic partitioning and successful in heterosexual calling is still unknown, leading one to believe that the full range of selection pressures exerted on heterosexual calls depend on a better understanding of the local bioacoustic spectrum (Chek et al., 2003).

In studies developed with birds it was identified that the multispecific choruses are structured by acoustic spatial timing and organized in acoustic signalling assemblies that determine the acoustic niche of the species (Tobias et al., 2013). For anurans it is necessary to invest in research to better understand the intra and interspecific associations, since the hypothesis of spectral partitioning must consider time, domain, the void filling gaps of acoustic space intra and interspecific, and especially which statistical tools best evaluate the data without generating interpretative vies (Amézquita et al., 2011).

The bioacoustic features of most species in our study were congruent with the previous descriptions (Cardoso and Vielliard, 1985; Hödl, 1992; Bastos et al., 2003; Guimarães and Bastos, 2003; Heyer and Reid, 2003; Martins and Jim, 2003; Nunes and Juncá, 2006; Silva et al., 2008; Vilaça et al., 2011; Jansen and Schulze, 2012; Gambale and Bastos, 2014; Toledo et al., 2014). One exception was Scinax ruber whose advertisement call registered in Colombia (Bernal et al., 2004) was very different from our results from Piauí. We found a higher dominant frequency and shorter notes with more pulses in comparison to these authors. These differences may be due to the fact that S. ruber is a complex of different cryptic species that needs a taxonomic revision (De la Riva et al., 2000). In addition, we presented here a redescription of the advertisement call of the species Dendropsophus rubicundulus and Pleurodema diplolister using modern technology. Instead of being repetitive data, descriptions of the morphology and bioacoustics of a species throughout its geographic distribution are important for taxonomy and ecology as well once it can indicate a clinal variance in the features (Heyer and Reid, 2003).

The advertisement call is considered a conservative character in the evolution of anurans, with closely related taxonomic groups sharing similarities in calling patterns (Duellman and Trueb, 1994; Ryan, 2001). If the properties of the call are capable of separating taxonomically a group of species as seen in Figure 14, they will be able to segregate these same species in the acoustic niches. The incongruence related to the species Pleurodema diplolister, that was not clustered with the remaining Leptodactylidae, is due that the cluster analysis is not a phylogenetic approach, and was used only to demonstrate the similarities and/or dissimilarities among the bioacoustic features of the analysed species, as the goal of this study was not phylogenetic, but to demonstrate the similarities and dissimilarities of the calls, this incongruence cannot be considered a vies.

Leiuperinae subfamily was previously diagnosed as family Leiuperidae (Frost et al., 2006). More recently the status of Leiuperinae as a subfamily was revalidated (Alexander Pyron and Wiens, 2011; Frost 2017), in the present study Leiuperinae species recorded, according to bioacoustics similarities, are clustered within Leptodactylidae. Physalaemus nattereri, formerly allocated in the genus Eupemphix, is currently classified as Physalaemus (Alexander Pyron and Wiens, 2011; Faivovich et al., 2012), which is corroborated by the bioacoustic similarity with P. cuvieri (see Figure 14). Physalaemus nattereri and P. cuvieri showed shorter non-pulsed calls when compared to Pleurodema diplolister, although they are of the same subfamily. Pleurodema diplolister has a completely distinct advertisement call, reflecting the unique bioacoustic features that identify the species such as longer calls with multiple pulses with a higher call rate (see Table 1), which allows its sympatric occurrence with $P$. nattereri and $P$. cuvieri. Notwithstanding the similarity in bioacoustic features, the non-interference between $P$. nattereri and $P$. cuvieri is possible due to differences in the use of space and period of vocalization (Salas et al., 1998). Despite the similarities in call frequencies and in the use of vocalization sites, differences in call duration decrease the overlap between these species and, consequently, the levels of acoustic interference (Silva et al., 2008). Moreover, P. cuvieri shows decreasing mean modulation of $186.6 \mathrm{~Hz}$, while $P$. nattereri does not exhibit any modulation in its dominant frequency. Furthermore, the intra-specific identification process in a chorus composed of closely related species with similar calling patterns can be performed by the combination of spectral bioacoustic characteristics, and temporal features associated with the behaviour of the calling males as well (Cardoso and Vielliard, 1990; Martins et al., 2006).

Among Leptodactylus fuscus and L. vastus there are more than $95 \%$ of general similarity in the acoustic features 


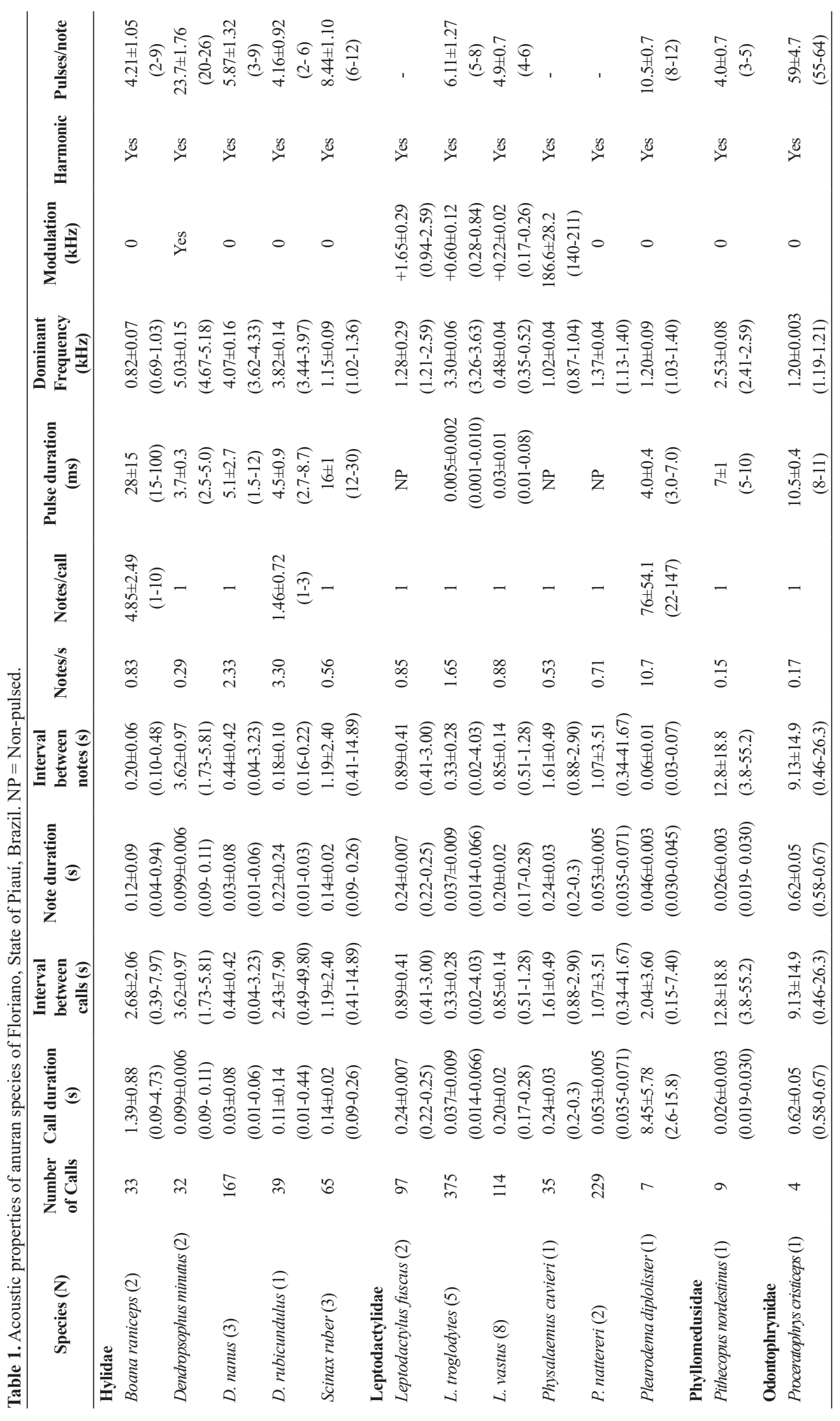


Table 2. Analysis of variance (ANOVA) of the pulse duration of the species with pulsed calls. $\mathrm{s}=$ significant; ns $=$ non-significant.

\begin{tabular}{crccc}
\hline Species & F & p & DF & \\
\hline Boana raniceps & 0.69 & $=0.5568$ & 231 & $\mathrm{~ns}$ \\
Dendropsophus minutus & 4.30 & $<0.0001$ & 639 & $\mathrm{~s}$ \\
Dendropsophus nanus & 27.79 & $<0.0001$ & 806 & $\mathrm{~s}$ \\
Dendropsophus rubicundulus & 4.81 & $=0.0093$ & 170 & $\mathrm{~s}$ \\
Leptodactylus troglodytes & 7.09 & $<0.0001$ & 60 & $\mathrm{~s}$ \\
Leptodactylus vastus & 11.91 & $<0.0001$ & 90 & $\mathrm{~s}$ \\
Pithecopus nordestinus & 3.90 & $=0.0182$ & 33 & $\mathrm{~s}$ \\
Pleurodema diplolister & 13.01 & $<0.0001$ & 484 & $\mathrm{~s}$ \\
Proceratophrys cristiceps & 0.75 & $=0.8947$ & 219 & $\mathrm{~ns}$ \\
Scinax ruber & 1.22 & $=0.2946$ & 199 & $\mathrm{~ns}$ \\
\hline
\end{tabular}

(see Figure 14). However, due to its large body size, the call of $L$. vastus shows relatively lower frequency when compared to other species. Because of this it was allocated in a different branch of the cluster. Differently from L. vastus, L. fuscus exhibits higher call frequency with increasing mean modulation of $1,650.8 \mathrm{~Hz}$. The levels of interference among species should be reduced, or even absent, in a shared acoustic space according to the differences in the frequency, duration and rhythms of vocalizations (Duellman and Trueb, 1994). However, this is a not resolved question, mainly because a variety of species have individuals of a broad band of auditory tuning outside the range of its own species, and a spectral segregation may not ensure a noise-free channel of communication (Wells, 2007).

The coexistence of species, ecologically and phylogenetically related, can be explained by reduction in interspecific competition (Duellman, 1978; Rossa-Feres and Jim, 2001; Martins et al., 2006). Such competition is reduced when diversity is lower than 17 sympatric species (Silva et al., 2008). In the present study only 13 species were found sharing the acoustic space. Therefore, considering the threshold suggested by Silva et al. (2008), lower levels of interspecific interaction and competitive interference among the species are expected. The environmental factors of the study area, such as reduced rainy season and homogeneous structure of the vocalization site, limit the periods and sites of reproduction respectively. Concomitantly, the reduced rainy season concentrates the occurrence of the anurans in time and the homogeneous structure of the environment concentrates the occurrence of the anurans in space. In one hand these aspects should increase the competition, but in the other hand these aspects are the same that maintains the diversity of anurans in a low rate. This fact contributes to a reduced number of species and, consequently, low competition levels in the bioacoustic niche (Silva et al., 2008). A similar outcome was found by Sinsch et al. (2012), where an afromontane community reached the maximum of 15 species without niche overlap.

Although there are certain levels of acoustic niche overlap among sympatric species, the unique spectral and temporal patterns of the calls produced by each species tend to minimize interspecific interference. This knowledge is important for understanding the ecological behaviour of the species and the biodiversity composition of a site, mainly in this poorly known biome. Future studies comparing the bioacoustic overlap of allopatric versus sympatric species could provide understanding of the coevolution of the bioacoustics among anurans as a form of sympatric differentiation.

\section{Acknowledgements}

We thank Guilherme Muricy (Universidade Federal do Rio de Janeiro/Museu Nacional) and Michael J. Ryan (University of Texas, Austin) for their critical analysis on the manuscript, and ICMBIO/SISBIO for the authorization for collection and Cornell Lab for the software Raven Pro.

\section{References}

AMÉZQUITA, A., FLECHAS, S.V., LIMA, A.P., GASSER, H. and HÖDL, W. 2011. Acoustic interference and recognition space within a complex assemblage of dendrobatid frogs. PNAS, vol. 108 , no. 41, pp. 17058-17063.

BASTOS, R.P. and HADDAD, C.F.B., 1999. Atividade reprodutiva de Scinax rizibilis (Bokermann) (Anura, Hylidae) na Floresta Atlântica, sudeste do Brasil. Revista Brasileira de Zoologia, vol. 16, no. 2, pp. 409-421. http://dx.doi.org/10.1590/ S0101-81751999000200007.

BASTOS, R.F., MOTTA, J.A.O., LIMA, L.P. and GUIMARÃES, L.D. 2003. Anfibios da Floresta Nacional de Silvânia, Estado de Goiás. Goiânia: Stylo Gráfica e Editora, 82 p.

BASTOS, R.P., SIGNORELLI, L., MORAIS, A.R., COSTA, T.B., LIMA, L.P. and POMBAL JÚNIOR, J.P., 2011. Advertisement calls of three anuran species (Amphibia) from the Cerrado, Central Brazil. South American Journal of Herpetology, vol. 6, no. 2, pp. 67-72. http://dx.doi.org/10.2994/057.006.0204.

BERNAL, M.H., MONTEALEGRE, D.P. and PAEZ, C.A., 2004. Estudio de la vocalización de trece espécies de anuros del município de Ibagué, Colombia. Zoologia, vol. 28, no. 108, pp. $385-390$

CARDOSO, A.J. and VIELLIARD, J.M.E., 1985. Caracterização bio-acústica da população topotípica de Hyla rubicundula (Amphibia, 
Anura). Revista Brasileira de Zoologia, vol. 2, no. 7, pp. 423-426. http://dx.doi.org/10.1590/S0101-81751984000300002.

CARDOSO, A.J. and VIELLIARD, J.M.E., 1990. Vocalização de anfíbios anuros de um ambiente aberto, em Cruzeiro do Sul, Estado do Acre. Brazilian Journal of Biology $=$ Revista Brasileira de Biologia, vol. 50, pp. 229-242.

CORNELL LAB, 2011 [viewed 12 September 2013]. Bioacoustics research program. Raven Pro: interactive sound analysis software (version 1.4) [online]. Ithaca: The Cornell Lab of Ornithology. Available from: http://www.birds.cornell.edu/raven.

CHEK, A.A., BOGART, J.P. and LOUGHEED, S.C., 2003. Mating signal partitioning in multi-species assemblages: a null model test using frogs. Ecology Letters, vol. 6, no. 3, pp. 235-247. http://dx.doi.org/10.1046/j.1461-0248.2003.00420.x.

DE LA RIVA, I., KÖHLER, J. and LÖTTERS, S., 2000. Ten years of research on Bolivian amphibians: updated checklist, distribution, taxonomic problems, literature and iconography. Revista Espagnola di Herpetologia, vol. 14, pp. 19-164.

DUELLMAN, W.E., 1978. The biology of an equatorial herpetofauna in Amazonian Ecuador. Miscellaneous Publication. Museum of Natural History, University of Kansas, vol. 65, pp. 1-352.

DUELLMAN, W.E. and TRUEB, L. 1994. Biology of amphibians. Baltimore, USA: Ed. Johns Hopkins.670 p.

FAIVOVICH, J., FERRARO, D.P., BASSO, N.G., HADDAD, C.F.B., RODRIGUES, M.T., WHEELER, W.C. and LAVILLA, E.O., 2012. A phylogenetic analysis of Pleurodema (Anura: Leptodactylidae: Leiuperinae) based on mitochondrial and nuclear gene sequences, with comments on the evolution of anuran foam nests. Cladistics, vol. 28, no. 5, pp. 460-482. http://dx.doi. org/10.1111/j.1096-0031.2012.00406.x.

FROST, D.R. 2017. [viewed 13 February 2017]. Amphibian species of the world: an online reference. Version 6.0. [online]. Electronic Database. Available from: http://research.amnh.org/ herpetology/amphibia/index.html.

FROST, D.R., GRANT, T., FAIVOVICH, J., BAIN, R.H., HAAS, A., HADDAD, C.F.B., SÁ, R.O., CHANNING, A., WILKINSON, M., DONNELLAN, S.C., RAXWORTHY, C.J., CAMPBELL, J.A., BLOTTO, B.L., MOLER, P., DREWES, R.C., NUSSBAUM, R.A., LYNCH, J.D., GREEN, D.M. and WHEELER, W.C. 2006. The amphibiam tree of life. Bulletim of the Americam Museum of Natural History, vol. 297, pp. 1-370.

GAMBALE, P.G. and BASTOS, R.P., 2014. Vocal repertoire and bioacoustic analyses in Physalaemus cuvieri (Anura, Leptodactylidae) from southern Brazil. The Herpetological Journal, vol. 24, pp. 31-39.

GERHARDT, H.C., 1994. The evolution of vocalization in frogs and toads. Annual Review of Ecology and Systematics, vol. 25, no. 1, pp. 293-324. http://dx.doi.org/10.1146/annurev. es.25.110194.001453.

GERHARDT, H.C. and HUBER, F., 2002. Acoustic communication in insects and anurans: common problems and diverse solutions. Chicago: The University of Chicago Press, $531 \mathrm{p}$.

GUIMARÃES, L.A. and BASTOS, R.P.B. 2003. Vocalizações e interações acústicas em Hyla raniceps (Anura, Hylidae) durante a atividade reprodutiva. Iheringia, vol. 93, no. 2, pp. 149-158. http://dx.doi.org/10.1590/S0073-47212003000200005.

HEYER, W.R. and REID, Y.R., 2003. Does advertisement call variation coincide with genetic variation in the genetically diverse frog taxon currently known as Leptodactylus fuscus (Amphibia: Leptodactylidae)? Anais da Academia Brasileira de Ciências, vol. 75, no. 1, pp. 39-54. http://dx.doi.org/10.1590/ S0001-37652003000100006. PMid:12715049.

HEYER, W.R., RAND, A.S., CRUZ, C.A.G., PEIXOTO, O.L. and NELSON, C.E., 1990. Frogs of Boracéia. Arquivos de Zoologia, vol. 31, pp. 231-410.

HÖDL, W., 1992. Reproductive behavior in the neotropical foam-nesting frog Pleurodema diplolister (Leptodactylidae). Amphibia-Reptilia, vol. 13, no. 3, pp. 263-274. http://dx.doi. org/10.1163/156853892X00472.

INSTITUTO NACIONAL DE METEOROLOGIA - INMET, 2015 [viewed 12 September 2015]. Estações automáticas [online]. Available from: http://www.inmet.gov.br/portal/index. php? $\mathrm{r}=$ estacoes/estacoesautomaticas.

JANSEN, M. and SCHULZE, A., 2012. Molecular, morphology and bioacoustic data suggest Bolivian distribution of a large species of the Leptodactylus pentadactylus group (Amphibia: Anura: Leptodactylidae). Zootaxa, vol. 3307, pp. 35-47.

KOK, F.J.R. and KALAMANDEEN, M., 2008. Introduction to the taxonomy of the amphibians of Kaieteur National Park, Guyana. ABC Taxa, vol. 5, pp. 1-278.

KÖHLER, J., JANSEN, M., RODRÍGUEZ, A., KOK, P.J.R., TOLEDO, L.F., EMMRICH, M., GLAW, F., HADDAD, C.F.B. RÖDEL, M.O., and VENCES M., 2017. The use of bioacoustic in anuran taxonomy: theory, terminology, methods and recommendations for best practice. Zootaxa, vol. 4251, no. 1, 1-124. https://doi.org/10.11646/zootaxa.4251.1.1

KRAUSE, B.L., 1987. The niche hypothesis: how animals taught us to dance and sing. Whole Earth Review, no. 57.

LEGENDRE, P. and LEGENDRE, L., 1998. Numerical ecology. Amsterdam: Elsevier Science BV, 870 p.

LOMOLINO, M.V., PIJANOWSKI, B.C. and GASC, A. 2015. The silence of biogeography. Journal of Biogeography, vol. 42, no. 7, pp. 1187-1196. http://doi:10.1111/jbi.12525.

MARTINS, I.A. and JIM, J., 2003. Bioacoustic analysis of advertisement call in Hyla nana and Hyla sanborni (Anura, Hylidae) in Botucatu, São Paulo, Brazil. Brazilian Journal of Biology $=$ Revista Brasileira de Biologia, vol. 63, no. 3, pp. 507-516. http://dx.doi.org/10.1590/S1519-69842003000300017. PMid:14758710.

MARTINS, I.A. and JIM, J., 2004. Advertisement call of Hyla jimi and Hyla elianeae (Anura, Hylidae) in Botucatu Region, São Paulo, Brazil. Brazilian Journal of Biology $=$ Revista Brasileira de Biologia, vol. 64, no. 3B, pp. 645-654. http://dx.doi.org/10.1590/ S1519-69842004000400012. PMid:15620003.

MARTINS, I.A., ALMEIDA, S.C. and JIM, J., 2006. Calling sites and acoustic partitioning in species of the Hyla nana and rubicundula groups (Anura, Hylidae). The Herpetological Journal, vol. 16, pp. 239-247.

NUNES, I. and JUNCÁ, F.A., 2006. Advertisement calls of three Leptodactylidae frogs in the State of Bahia, Northeastern Brazil (Amphibia, Anura, Leptodactylidae), with considerations on their taxonomic status. Arquivos do Museu Nacional. Museu Nacional (Brazil), vol. 64, no. 2, pp. 151-157.

PREFEITURA MUNICIPAL DE FLORIANO - PMF, 2015 [viewed 28 September 2015]. A cidade de Floriano [online]. Available from: http://www.floriano.pi.gov.br/floriano.php. 
PIJANOWSKI, B.C., VILLANUEVA-RIVERA, L.J., DUMYAHN, S.L., FARINA, A., KRAUSE, B.L., NAPOLETANO, B.M., GAGE, S.H. and PIERETTI, N. 2011. The science of sound in the landscape. BioScience, vol. 61, no. 3, pp. 203-216. http://doi 10.1525/bio.2011.61.3.6.

POMBAL JUNIOR, J.P., 2010. O espaço acústico em uma taxocenose de anuros (Amphibia) do Sudeste do Brasil. Arquivos do Museu Nacional. Museu Nacional (Brazil), vol. 68, no. 1-2, pp. 135-144.

ALEXANDER PYRON, R. and WIENS, J.J., 2011. A largescale phylogeny of Amphibia including over 2800 species, and a revised classification of extant frogs, salamanders, and caecilians. Molecular Phylogenetics and Evolution, vol. 61, no. 2, pp. 543-583. http://dx.doi.org/10.1016/j.ympev.2011.06.012. PMid:21723399.

ROSSA-FERES, D.C. and JIM, J., 2001. Similaridade do sítio de vocalização em uma comunidade de anfíbios anuros na região noroeste do Estado de São Paulo, Brasil. Revista Brasileira de Zoologia, vol. 18, no. 2, pp. 439-454. http://dx.doi.org/10.1590/ S0101-81752001000200015.

RYAN, M.J. 2001. Anuran communication. Washington: Smithsonian Institution Pres. $252 \mathrm{p}$.

SALAS, N.E., ZAVATTIERI, M.V., DI-TADA, I.E., MARTIN, A.L. and BRIDALLORI, M.E., 1998. Bioacoustical and ethoecological features in Amphibia communities of Southern Cordoba province (Argentina). Cuadernos de Herpetología, vol. 12, no. 1 , pp. 37-46.

SCHIMIDT, A.K.D., RIEDE, K. and RÖMER, H. 2015. No phenotypic signature of acoustic competition in songs of a tropical cricket assemblage. Behavioral Ecology, vol. 27, no. 1, pp. 211-218. http://doi:10.1093/beheco/arv141.
SILVA, R.A., MARTINS, I.A. and ROSSA-FERES, D.C., 2008. Bioacústica e sítio de vocalização em taxocenoses de anuros de área aberta no noroeste paulista. Biota Neotropica, vol. 8, no. 3, pp. 123-134. http://dx.doi.org/10.1590/S1676-06032008000300012.

SINSCH, U., LÜMKEMANN, K., ROSAR, K., SCHWARZ, C. and DEHLING, M., 2012. Acoustic niche partitioning in an anuran community inhabiting an Afromontane wetland (Butare, Rwanda). African Zoology, vol. 47, no. 1, pp. 60-73. http://dx.doi. org/10.1080/15627020.2012.11407524.

TOBIAS, J.A., PLANQUÉ, R., CRAM, D.L. and SEDDON, N. 2013. Species interactions and the structure of complex communication networks. PNAS, vol. 111, no. 3, pp. 1020-1025. http://doi/10.1073/pnas.1314337111.

TOLEDO, L.F., MARTINS, I.A., BRUSCHI, D.P., PASSOS, M.A. and ALEXANDRE, C. and HADDAD, C.F.B., 2014. The anuran calling repertoire in the light of social context. Acta Ethologica, vol. 18, no. 2, pp. 87-99. http://dx.doi.org/10.1007/ s10211-014-0194-4.

VILAÇA, T.R.A., SILVA, J.R.S. and SOLÉ, M., 2011. Vocalization and territorial behaviour of Phyllomedusa nordestina Caramaschi, 2006 (Anura: Hylidae) from southern Bahia, Brazil. Journal of Natural History, vol. 45, no. 29-30, pp. 1823-1834. http://dx.doi. org/10.1080/00222933.2011.561018.

WELLS, K.D. 2007. The ecology and behavior of amphibians. Chicago: The University of Chicago Press. 1148 p. http://dx.doi. org/10.7208/chicago/9780226893334.001.0001.

WOGEL, H., ABRUNHOSA, P.A. and POMBAL-JR, J.P. 2002. Atividade reprodutiva de Physalaemus signifer (Anura, Leptodactylidae) em ambiente temporário. Iheringia, vol. 92, no. 2, pp. 57-70. http://dx.doi.org/10.1590/S0073-47212002000200006. 